\title{
Front Matter: Volume 11385
}

, "Front Matter: Volume 11385," Proc. SPIE 11385, Optics and Measurement International Conference 2019, 1138501 (30 December 2019); doi:

$10.1117 / 12.2564596$

SPIE Event: Optics and Measurement 2019 International Conference, 2019, SPIE. Liberec, Czech Republic 


\title{
PROCEEDINGS OF SPIE
}

\section{Optics and Measurement International Conference 2019}

\author{
Jana Kovačičinová \\ Editor
}

\section{8-10 October 2019 \\ Liberec, Czech Republic}

Sponsored by

asphericon $\mathrm{GmbH}$ (Germany)

CRYTUR, spol.s s. o. (Czech Republic)

FHR Anlagenbau GmbH (Germany)

OptiXs, s. r. o. (Czech Republic)

OptoTech Optikmaschinen GmbH (Germany)

POLPUR ${ }^{T M}$, spol. s r.o. (Czech Republic)

Carl Zeiss spol. s.r.o. (Czech Republic)

Meopta - optika, s.r.o. (Czech Republic)

Organized by

Institute of Plasma Physics of the CAS - Regional Centre for Special Optics and Optoelectronic Systems TOPTEC (Czech Republic)

Published by

SPIE 
The papers in this volume were part of the technical conference cited on the cover and title page. Papers were selected and subject to review by the editors and conference program committee. Some conference presentations may not be available for publication. Additional papers and presentation recordings may be available online in the SPIE Digital Library at SPIEDigitallibrary.org.

The papers reflect the work and thoughts of the authors and are published herein as submitted. The publisher is not responsible for the validity of the information or for any outcomes resulting from reliance thereon.

Please use the following format to cite material from these proceedings:

Author(s), "Title of Paper," in Optics and Measurement International Conference 2019, edited by Jana Kovačičinová, Proceedings of SPIE Vol. 11385 (SPIE, Bellingham, WA, 2019) Seven-digit Article CID Number.

ISSN: 0277-786X

ISSN: 1996-756X (electronic)

ISBN: 9781510635470

ISBN: 9781510635487 (electronic)

Published by

SPIE

P.O. Box 10, Bellingham, Washington 98227-0010 USA

Telephone +1 3606763290 (Pacific Time) · Fax + 13606471445

SPIE.org

Copyright @ 2019, Society of Photo-Optical Instrumentation Engineers.

Copying of material in this book for internal or personal use, or for the internal or personal use of specific clients, beyond the fair use provisions granted by the U.S. Copyright Law is authorized by SPIE subject to payment of copying fees. The Transactional Reporting Service base fee for this volume is $\$ 21.00$ per article (or portion thereof), which should be paid directly to the Copyright Clearance Center (CCC), 222 Rosewood Drive, Danvers, MA 01923. Payment may also be made electronically through CCC Online at copyright.com. Other copying for republication, resale, advertising or promotion, or any form of systematic or multiple reproduction of any material in this book is prohibited except with permission in writing from the publisher. The CCC fee code is 0277$786 \times / 19 / \$ 21.00$.

Printed in the United States of America by Curran Associates, Inc., under license from SPIE.

Publication of record for individual papers is online in the SPIE Digital Library.

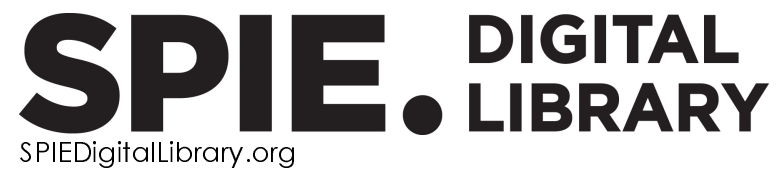

Paper Numbering: Proceedings of SPIE follow an e-First publication model. A unique citation identifier (CID) number is assigned to each article at the time of publication. Utilization of CIDs allows articles to be fully citable as soon as they are published online, and connects the same identifier to all online and print versions of the publication. SPIE uses a seven-digit CID article numbering system structured as follows:

- The first five digits correspond to the SPIE volume number.

- The last two digits indicate publication order within the volume using a Base 36 numbering system employing both numerals and letters. These two-number sets start with $00,01,02,03,04$, 05, 06, 07, 08, 09, OA, OB ... 0Z, followed by 10-1Z, 20-2Z, etc. The CID Number appears on each page of the manuscript. 


\title{
Contents
}

\author{
$\checkmark \quad$ Authors \\ vii Conference Committees \\ ix Introduction
}

OPTICS AND MEASUREMENT INTERNATIONAL CONFERENCE 2019

1138502 Preliminary design of longitudinal chromatic aberration sensor implemented to laser processing head [11385-3]

1138503 Graphical method to determine exact scan patterns generated with rotational Risley prisms [11385-5]

1138504 Investigation of dental cavities: between x-ray radiography and OCT [11385-19]

1138505 Study of the influence of focal position on back-reflected radiation during deep penetration laser welding and its simulation [11385-11]

1138506 Measurement of mechanical properties of GRIN rod lens [11385-20]

1138507 Metallic fractures assessments: OCT versus SEM [11385-22]

1138508 lon beam figuring using Einzel lens [11385-14]

1138509 Ultra-precise surface machining of N-BK7 using microwave-driven reactive plasma jet machining [11385-31]

11385 OA Lens holder optimization for production of high precise hemispheres [11385-16]

11385 OB Modular laser beam distribution system for the HiLASE Center [1 1385-4]

$113850 \mathrm{C} \quad$ Laser rods characterization by Fourier transform phase-shifting interferometry [11385-30]

11385 OD Mobile LIDT [11385-9]

$11385 \mathrm{OE} \quad$ Coherence scanning interferometry with two polarization states [11385-12]

11385 OF Photometry of exoplanet transits and their regular monitoring [1 1385-24]

11385 OG Investigation of tympanic membrane shape using digital holography [1 1385-35] 
$11385 \mathrm{OH} \quad$ All-spherical Cassegrain telescope with a Volosov corrector [1 1385-8]

$11385 \mathrm{Ol} \quad$ Sub-aperture stitching computation time optimization using linear equations system [1 1385-1]

$113850 \mathrm{~J} \quad$ Machining vibration and methods of their measurements [1 1385-13]

11385 OK Eu:Lu2O $\quad$ E transparent ceramics prepared by spark-plasma-sintering [1 1385-26]

11385 OL Optical design of the RODES hyperspectral LWIR imager [1 1385-28]

11385 OM Measurement of small optics by use of a multi-wavelength interferometrical approach [11385-21] 


\section{Authors}

Numbers in the index correspond to the last two digits of the seven-digit citation identifier (CID) article numbering system used in Proceedings of SPIE. The first five digits reflect the volume number. Base 36 numbering is employed for the last two digits and indicates the order of articles within the volume. Numbers start with 00, 01, 02, 03, 04, 05, 06, 07, 08, 09, OA, OB...0Z, followed by 10-1Z, 20-2Z, etc.

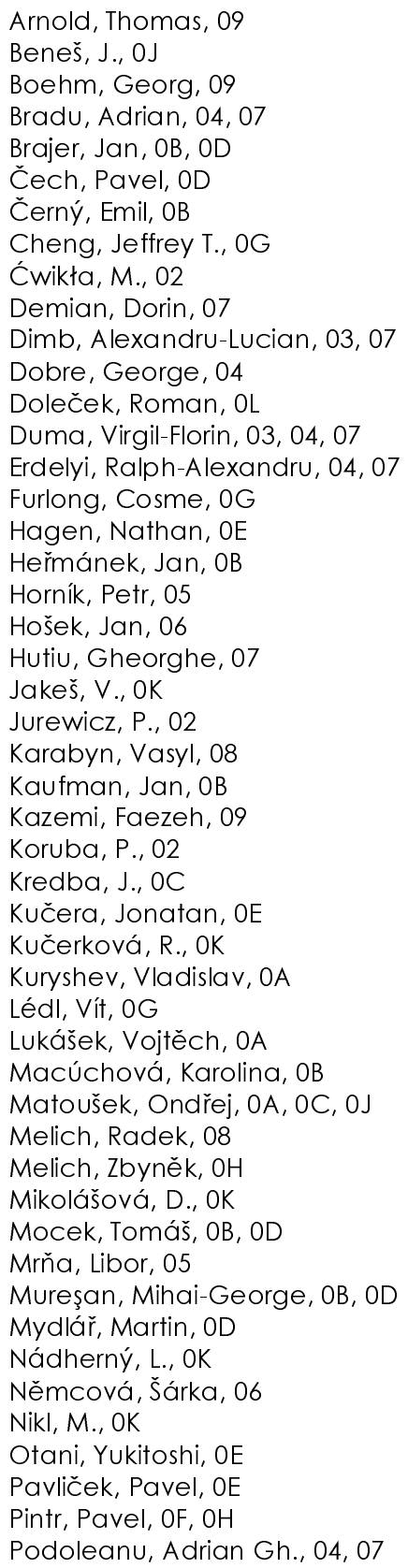

Polák, Jaroslav, 08

Pooladvand, Koohyar, 0G

Procháska, František, 08, 0C, 0J

Prưša, F., OK

Psota, Pavel, OG

Rail, Zdeněk, $\mathrm{OF}, \mathrm{OH}$

Řeháková, Martina, OB

Reiner, J., 02

Rosowski, John J., OG

Rubešová, K., OK

Šarbort, Martin, 05

Šebestová, Hana, 05

Šimko, Martin, OA

Špína, M., OJ

Stašík, Marek, ol

Tang, Haimi, OG

Thoř, Tomáš, OH, OK

Václavík, Jan, OL

Vanda, Jan, OD

Vápenka, David, $\mathrm{OF}, \mathrm{OH}$

Veselý, Martin, $\mathrm{OL}$

Wendel, Marc, OM

Zakrzewski, A., 02 
Proc. of SPIE Vol. 11385 1138501-6

Downloaded From: https://www.spiedigitallibrary.org/conference-proceedings-of-spie on 26 Apr 2023
Terms of Use: https://www.spiedigitallibrary.org/terms-of-use 


\title{
Conference Committees
}

\author{
Conference Chairs
}

Jana Kovačičinová, Institute of Plasma Physics of the CAS, v.v.i.

(Czech Republic)

Karel Žídek, Institute of Plasma Physics of the CAS, v.v.i. (Czech Republic)

Scientific \& Review Committee

Josef Lazar, Institute of Scientific Instruments of the CAS (Czech Republic)

Vít Lédl, Institute of Plasma Physics of the CAS, v.v.i. (Czech Republic)

Pavel Mokrý, Technical University of Liberec (Czech Republic)

František Procháska, Institute of Plasma Physics of the CAS, v.v.i.

(Czech Republic)

Pavel Psota, Institute of Plasma Physics of the CAS, v.v.i. (Czech Republic)

Lukáš Steiger, Institute of Plasma Physics of the CAS, v.v.i. (Czech Republic)

Miroslav Šulc, Technical University of Liberec (Czech Republic)

Jan Václavík, Institute of Plasma Physics of the CAS, v.v.i. (Czech Republic)

Program Committee

Jana Kovačičinová, Institute of Plasma Physics of the CAS, v.v.i.

(Czech Republic)

Jiří Beneš, Institute of Plasma Physics of the CAS, v.v.i. (Czech Republic)

Dana Marková, Institute of Plasma Physics of the CAS, v.v.i.

(Czech Republic)

Hana VIčková, Institute of Plasma Physics of the CAS, v.v.i.

(Czech Republic) 
Proc. of SPIE Vol. $113851138501-8$

Downloaded From: https://www.spiedigitallibrary.org/conference-proceedings-of-spie on 26 Apr 2023 Terms of Use: https://www.spiedigitallibrary.org/terms-of-use 


\section{Introduction}

The Institute of Plasma Physics of the CAS, v.v.i. (Czech Republic) has regularly organized the Optics and Measurement International Conference to share knowledge and experience gained in the field of research and development of optical elements, systems, and measurement methods. The conference is an opportunity to link the industrial and academic communities specialized in the above-mentioned field of optics.

The main topics of the Optics and Measurement International Conference 2019 were selected based on the latest technology and experience and focused on:

- design, production, and machining of optical elements from standard and non-standard materials using the latest procedures and technology;

- methods and systems for optical measurement; characterization of optical elements by interferometric, holographic, and other methods;

- computational and hyperdimensional imaging, technology of thin films deposition and its measurement;

- fine mechanics (construction and technology of mechanical parts and system manufacturing for using in optics);

- optical elements and advanced systems for highly specific application (radiation hard optics, x-ray and laser optics, diffractive optics and $\mathrm{HOE}$ elements, optical systems for space, etc.).

Since 2012, interesting scientific work and industrial applications have been presented at a high professional level at the Optics and Measurement International Conference. We believe that the conference continues to contribute to the establishment of new partnerships between the participating organizations. 
Proc. of SPIE Vol. 11385 1138501-10

Downloaded From: https://www.spiedigitallibrary.org/conference-proceedings-of-spie on 26 Apr 2023 Terms of Use: https://www.spiedigitallibrary.org/terms-of-use 